\title{
DIVERSITY, ABUNDANCE, STATUS AND ENDANGERED HABITATS OF AVIFAUNA IN SHEIKH BADIN NATIONAL PARK, DERA ISMAIL KHAN, KHYBER PAKHTUNKHWA, PAKISTAN
}

\author{
I. Ullah ${ }^{1}$, WU Qing-Ming ${ }^{1}$, Sun Xue-Ying ${ }^{1}$, M. S. Khan ${ }^{2}$, S. Ullah ${ }^{3}$, T. U. Khan ${ }^{4}$ and R. M. Nawaz \\ ${ }^{1}$ College of Wildlife and Protected Area, Northeast Forestry University, Harbin 150040, P. R. China. \\ ${ }^{2}$ Research Center for Eco- Environmental Sciences, University of Chinese Academy of Sciences, Beijing, 100085 China. \\ ${ }^{3}$ Shaheed Benazir Bhutto University Sheringal, Dir Upper \\ ${ }^{4}$ School of Nature Conservation, Beijing Forestry University, Beijing 100083, China \\ ${ }^{5}$ Department of Forestry, Faculty of Life Sciences, Shaheed Benazir Bhutoo University, Sheringal Dir Upper, Pakistan, \\ 18050. \\ *Corresponding author's email : qingmingwu@126.com
}

\begin{abstract}
Bird species richness and diversity are the key factors that determine the health and productivity of an ecosystem. They have occupied a marvelous place, i.e., they play a vital role in the contribution of public consideration towards natural habitats and considered as barometers of an ecosystem. This study was carried out to determine the bird species diversity of the Sheikh Badin National Park, located in District Dera Ismail Khan, Khyber Pakhtunkhwa, Pakistan. For this purpose, bird watching surveys following line transect method were conducted from June 2018 to July 2019 in the study area. A total 3408 individuals (1260 migrants and 2148 residents) representing the 41 bird species were recorded during the surveys. Among the total, 18 species were migrants and 23 residents, belong to 11 Orders and 25 Families. Passeriformes was the dominant encompass of 19 species ( 9 native and 10 migrants) and 13 families. This national park harbored species richness was $r=41$, Shannon-Weiner diversity index $\left(\mathrm{H}^{\prime}=3.546\right)$, evenness $\left(\mathrm{J}^{\prime} 0.955\right)$ and Simpson's Diversity $(\mathrm{D}=0.966)$. The foraging guild results revealed that the granivore $(2274)$ and insectivore $(565)$ were the most abundant bird species. The major threats to the avifauna were illegal hunting, grazing and deforestation.
\end{abstract}

Key words: National Park, Avifauna, Biodiversity, Habitat, Human Footprints, Hunting.

https://doi.org/10.36899/JAPS.2021.1.0218

Published online August 26, 2020

\section{INTRODUCTION}

The existence of a variety of organisms in a specific area shown their biological diversity. Biodiversity of a region indicates a total genes flow, species variation, and bio networks of that area. Species are the basic units of diversity which perform a vital role in a healthy ecosystem. Thus, investigation of the loss of species and destruction of the gene pool is a most critical challenge to the ecosystem (Trivedi, 1999). Bird fauna are so crucial for the balanced ecosystem as they play numerous roles as foragers, pollinators, insect pest predators, and also act as bioindicators in different kind of environment like suburbanization and industrialization (Sharma, 1982; Bhattacharjee and Hazarika, 1985) human pollution (Talukdar, 1997; Chakravarty, 1981) lighting (Sandhu and Dang, 1980). They are the first indicators of pollution problems and the purpose of given initial threatening (Gole, 1984; Becker, 2003).

In an ecosystem diversity of species acts as an essential factor to maintain it healthy. Birds have a marvelous place among other species as they are much appreciated by humans. Furthermore, birds also play a vital role in the contribution of public consideration towards natural habitats. Avian species are considered as barometers of an ecosystem. According to recent studies, numerous populations of avian species are claimed declining world widely, while, some of these gaining a status of locally extinct due to degradation of their habitats and fragmentation (Hewson et al., 2007).

It is world widely accepted that more than 1800 genera exist that give rise to roundabout 9702 avian species (Sibley and Monroe, 1990). Out of them, roughly 1300 bird species have been recorded from the Indian region (Manakadan and Pittie, 2001), while, Pakistan waterfronts cover a large chain of ecosystems that ultimately fascinates most diverse avifauna throughout the world to venture out their resources (Khan et al., 1996). According to a survey, 650 bird species founded in the country, and the presence also revealed a unique diversity in the world in three zoogeographical regions including Ethiopian, Palaearctic and Oriental, (Grimmett et al., 2001; Mirza and Wasiq, 2007). Additionally, in Pakistan, Indus flyway, is instantly being responsible for millions of resident and migratory birds shelter and food.

The leading causes of bird populations decline persisting over a long period may be due to unexpected 
changes such as pollution, shortage of food supply, interspecific interactions and global warming (Kushlan, 1993; Hetrick and Sieving, 2012). Status of bird species may be established by diagnosing threats and detecting further changes in the population of birds in the future are essential factors in minimizing the risk in their community (Amano et al., 2010b). However, incoming upcoming times, habitat loss, climate changes, (Yasué and Dearden, 2006), extinction and increasing numbers of species may cause a decline in bird population (Birdlife International, 2004). Similarly, bird extinctions occurred and $21^{\text {st }}$ population reductions in the present century ultimately cause disturbance in ecosystems and their processes (Luck et al., 2003).

The study was conducted first time in this national park and the main objective of the present research about avifauna diversity, abundance, status, endangered habitat for species, decline in bird species and to identify causes of this decline and suggest necessary actions for protection and conservation of bird population at the Sheikh Badin National Park, Dera Ismail Khan, Pakistan.

\section{MATERIALS AND METHODS}

Study Area: The present research was conducted in the Sheikh Badin National Park also spelt Sheikh Buddin National Park (32.297534 ${ }^{\circ} \mathrm{N}$ and $\left.70.805227^{\circ} \mathrm{E}\right)$, which is located in the southern part of Khyber Pakhtunkhwa (KP), Pakistan (Figure 1). It is situated among the Sheikh Badin Hills, which is an eastern extension of the Sulaimon Mountains at an elevation of $4600 \mathrm{ft}$. The park covers an area of 15,540 hectares. The park is situated with an altitude from $300-1350$ meters. Due to very high there are no specific arrangements for water supply, that's why the residential peoples make their man-made ponds, which is the only for restoring the water after the rain and later this water is utilized by every community like human, animals and birds. The weather in winter is very cold but in summer its very pleasant and mostly raining in summer. The residential birds are Chukor Alectoris chukar, see-see partridge - Ammoperdix griseogularis, black partridge - Francolinus francolinus and grey partridge - Predix predix, common myna Acridotheres tristis, house crow - Corvus splendens, house sparrow - Passer domesticus, red-vented bulbul Pycnonotus cafer, rock pigeon - Columba livia, eurasian collared doves - Streptopelia decaocto and baya weaver -Ploceus philippinus.

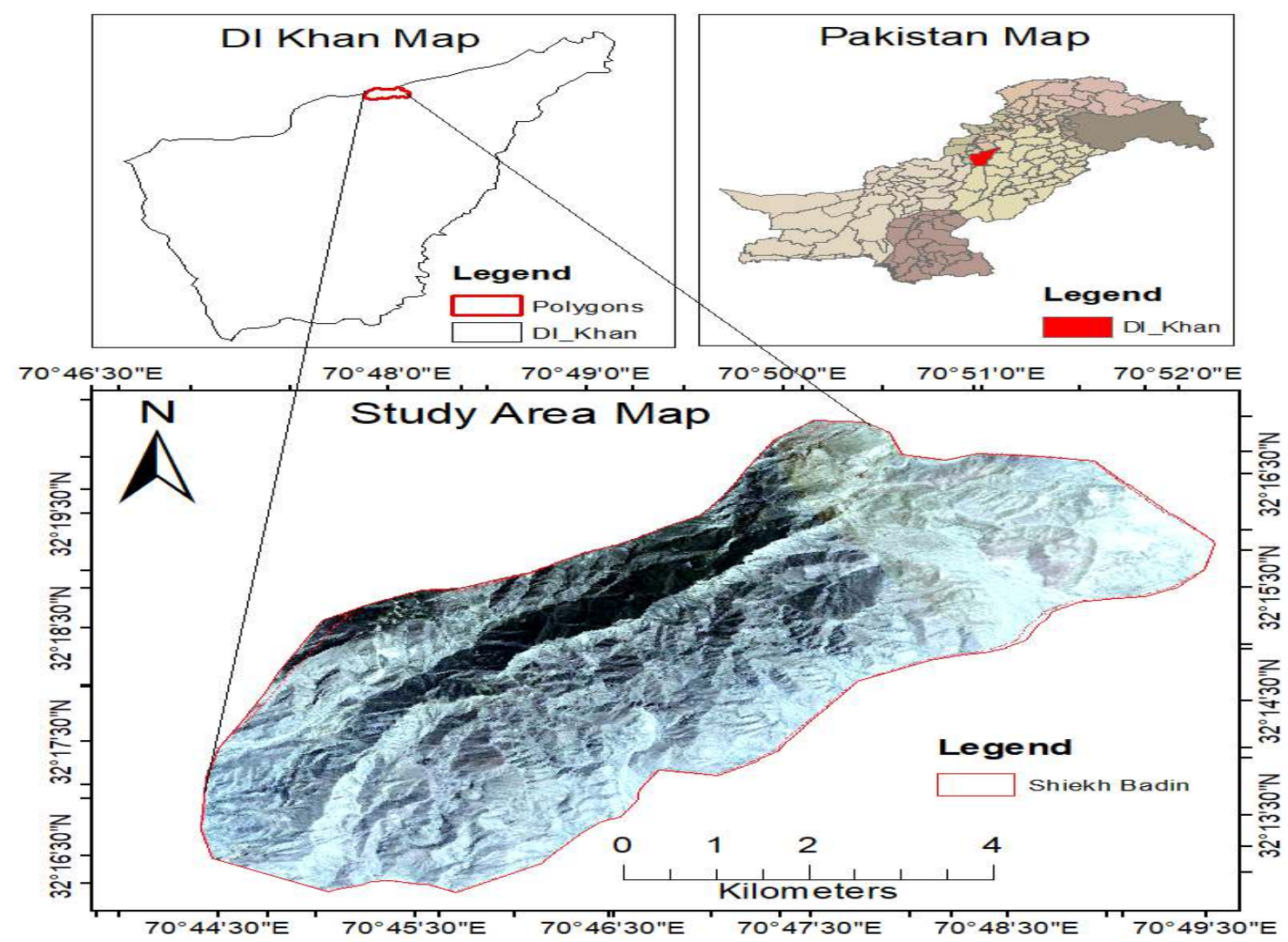

Fig.1. A GIS-based map showing the location of Conducted study sites at Sheikh Badin National Park, District Dera Ismail Khan, Pakistan. 
Bird Survey: For field data, we used the "Line Transect Method" method to collect our data, for a fixed period, of the year. The bird count surveys were conducted at dusk $(5-7 \mathrm{pm})$ and dawn $(6-8 \mathrm{am})$ assuming that the bird's activities are at the peak during these hours. The study site was visited once every month from June 2018 to July 2019. The birds were observed through binocular (42X) to confirm species identity and sometimes photographed with Nikon D7200 (Sigma 150-600 mm lens). The bird species were identified using the most authentic bird identification key for birds of Pakistan (Birds of Pakistan by Richard Grimmet, Tom Roberts and Tim Inskipp). The data was collected on a pre-designed field survey form.

Data Analysis: All the collected data were interned and stored in the Microsoft Excel Spreadsheet. We estimated the following parameters using that data:

I) We determined the relative abundance of bird species of the area using the following equation

$$
\text { 1- }(\text { R.A })=\frac{N}{N}
$$

Where

R.A: Relative Abundance

$\mathrm{N}=$ total number of individuals sighted of a bird species recorded during the surveys.

$\mathrm{N}=$ total number of individuals sighted of all bird species recorded during the surveys.

II) In studies related to avian fauna, it is always important to determine the diversity of bird species of an area. For this purpose Shannon-Weiner Index $\left(\mathrm{H}^{\prime}\right)$ was calculated in order to know the species diversity based on species abundance using the following equation:

where

$$
\text { 2-- }
$$

$\mathrm{H}^{\prime}=$ Diversity Index,

$\mathrm{Pi}=$ proportion of each bird species in the sample

LN $(\mathrm{Pi})=$ natural logarithm of this proportion.

III) Evenness is another important aspect of bird studies which needed to be determined. Evenness is basically the comparison of the similarity of the different bird species population size in a whole sample (all bird species). We calculated the Evenness Index $\left(\mathrm{J}^{\prime}\right)$ using the following formula.

\section{3------- $J=$}

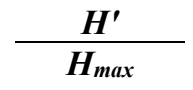

$\mathrm{H}^{\prime}=$ Diversity index

Hmax $=$ natural $\log$ of the total number of all bird species.

IV) We calculated the Simpson Index (D) which is the probability of any two individuals drawn from noticeably large community belonging to different species (Simpson, 1949).$$
4
$$
$\mathbf{D}=$
$\mathrm{N}=$ total number of individuals of a bird species sighted during the surveys.

$\mathrm{N}=$ total number of individuals of all bird species sighted during the surveys.

\section{RESULTS}

Wild bird Species Records: Bird watching surveys were conducted to record the diversity of avian fauna of the Sheikh Badin National Park. The wild bird species recorded in the park during the period from June 2018 to July 2019 are shown in Table 1. During this study a total number of 3408 individuals belonging to different bird species were sighted in the Sheikh Badin National Park. The total number of wild bird species found was 41 , with 18 seasonal and 23 residential, belonging to 11 Orders and 25 Families and. The order Passeriformes was the dominant order represented by 19 species from 13 families, including 9 species residential and 10 seasonal. Order Galliformes was in the second rank including five species from one family, one seasonal and 4 residential. Order Columbiformes represented by four species. While the lowest orders were Apodiformes, including one specie from Accipitridae family, Bucerotiformes, including one specie from Upupidae family, haradriiformes, including one specie from Charadriidae family and Passerine, including one specie from Muscicapidae family. In the Sheikh Buddin National Park species in descending order were recorded are House Sparrow (n: 252, R.A: 0.07), Blue-Checked Bee-Eater, Baya weaver, Alpine Swift, House Crow, Common Myna and Black-Breasted Weaver. 252, 219, 174,174, 147, 124. $0.07,0.06,0.05,0.05,0.04,0.04$ and 0.04 . The lowest relative abundance (0.01) was recorded for Chukar with just 14 individuals sighted Also, the species richness was $\mathrm{r}=41$, Shannon-Weiner diversity index $\left(\mathrm{H}^{\prime}=3.546\right)$, evenness $\left(\mathrm{J}^{\prime}\right.$ 0.955) and Simpson's Diversity $(\mathrm{D}=0.966)$.

Relative Abundance of Migrant Bird Species:Detail of migrant bird species observed at the Sheikh Badin National Park is presented in Table 3. The total of 1260 individuals of different migrant bird species was sighted in the Sheikh Badin National Park. The descending order of bird species found in our study area is Alpine Swift, Indian Robin, Common Quail, Spanish Sparrow, Baybacked shrike and Purple sunbird. They are highest as follows: 174, 115, 113, 108, 75 and 71 individuals. The relative abundances among wild bird species were 0.14 , $0.09,0.09,0.09,0.06$ and 0.06 , respectively. The lowest number of birds was twenty-one individuals with a relative abundance of 0.02 , for Common kestrel. Also, the species richness was $\mathrm{r}=18$, Shannon-Weiner diversity index $\left(\mathrm{H}^{\prime}=2.768\right)$, evenness $\left(\mathrm{J}^{\prime} 0.957\right)$ and Simpson's Diversity $(\mathrm{D}=0.930)$.

Relative Abundance of Residential Bird Species: The residential wild bird species recorded in the Sheikh Badin 
National Park were presented in Table 4. Total 2148 number of resident bird species recorded in the Sheikh Badin National Park. The descending order of species was: House Sparrow 252, Blue-Checked Bee-Eater 219, Baya weaver 174, House crow 147, Common Myna 124 and Black-Breasted Weaver 122. Their relative abundances were $0.12,0.1,0.08,0.07,0.06$ and 0.06 , respectively. Fourteen was the lowest number of individuals with relative abundance of 0.01 , for Chukur. Also, the species richness was $r=23$, Shannon-Weiner diversity index $\left(\mathrm{H}^{\prime}=2.957\right)$, evenness $\left(\mathrm{J}^{\prime} \quad 0.943\right)$ and Simpson's Diversity $(\mathrm{D}=0.940)$.

Table 1. Wild birds species recorded from the Sheikh Badin National Park.

\begin{tabular}{|c|c|c|c|c|c|c|}
\hline Order & & Family & English Name & Scientific Name & Status & IUCN \\
\hline \multicolumn{7}{|c|}{ Accipitriformes } \\
\hline & 1 & Accipitridae & Shikra & Accipiter badius & M & $\mathrm{LC}$ \\
\hline & 2 & & Common Buzzard & Buteo buteo & M & LC \\
\hline \multicolumn{7}{|c|}{ Apodiformes } \\
\hline \multicolumn{7}{|c|}{ Bucerotiformes } \\
\hline & 4 & Upupidae & Common Hoopoe & Uрира ерорs & $\mathrm{M}$ & $\mathrm{LC}$ \\
\hline \multicolumn{7}{|c|}{ Charadriiformes } \\
\hline & 5 & Charadriidae & Red-wattled lapwing & Vanellus indicus & $\mathrm{R}$ & $\mathrm{LC}$ \\
\hline \multicolumn{7}{|c|}{ Columbiformes } \\
\hline & 6 & Columbidae & Eurasian collared dove & Streptopelia decaocto & $\mathrm{R}$ & LC \\
\hline & 7 & & Red Collared Dove & Streptopelia tranquebarica & $\mathrm{R}$ & $\mathrm{LC}$ \\
\hline & 8 & & Spotted Dove & Spilopelia chinensis & $\mathrm{R}$ & LC \\
\hline & 9 & & Rock Pigeon & Columba livia & $\mathrm{R}$ & $\mathrm{LC}$ \\
\hline \multicolumn{7}{|c|}{ Coraciiformes } \\
\hline & 10 & Coraciidae & Indian Roller & Coracias benghalensis & $\mathrm{M}$ & LC \\
\hline & 11 & Meropidae & Blue-Checked Bee-Eater & Merops persicus & $\mathrm{R}$ & $\mathrm{LC}$ \\
\hline & 12 & & Green Bee-Eater & Merops orientalis & & $\mathrm{LC}$ \\
\hline \multicolumn{7}{|c|}{ Cuculiformes } \\
\hline & 13 & Cuculidae & Asian koel & Eudynamys scolopacea & $\mathrm{R}$ & $\mathrm{LC}$ \\
\hline & 14 & & Pied Cuckoo & Clamator jacobinus & M & LC \\
\hline & 15 & Cuculiformes & Greater coucal & Centropus sinensis & $\mathrm{R}$ & $\mathrm{LC}$ \\
\hline \multicolumn{7}{|c|}{ Falconiformes } \\
\hline & 16 & Falconidae & common kestrel & Falco tinnunculus & $\mathrm{M}$ & $\mathrm{LC}$ \\
\hline \multicolumn{7}{|c|}{ Galliformes } \\
\hline & 17 & Phasianidae & Black Francolin & Francolinus francolinus & $\mathrm{R}$ & $\mathrm{LC}$ \\
\hline & 18 & & Chukar & Alectoris chukar & $\mathrm{R}$ & $\mathrm{LC}$ \\
\hline & 19 & & Common Quail & Coturnix coturnix & $\mathrm{M}$ & LC \\
\hline & 20 & & Grey Francolin & Francolinus pondicerianus & $\mathrm{R}$ & LC \\
\hline & 21 & & See-See Partridge & Ammoperdix griseogularis & $\mathrm{R}$ & $\mathrm{LC}$ \\
\hline \multicolumn{7}{|c|}{ Passeriformes } \\
\hline & 22 & Laniidae & Bay-backed shrike & Lanius vittatus & M & LC \\
\hline & 23 & & Red Backed Shrike & Lanius collurio & M & $\mathrm{LC}$ \\
\hline & 24 & Sturnidae & Common Myna & Acridotheres tristis & $\mathrm{R}$ & $\mathrm{LC}$ \\
\hline & 25 & Muscicapidae & Common Stone Chat & Saxicola rubicola & $\mathrm{R}$ & $\mathrm{LC}$ \\
\hline & 26 & & Indian Robin & Copsychus fulicatus & M & LC \\
\hline & 27 & & Isabelline Wheatear & Oenanthe isabellina & M & $\mathrm{LC}$ \\
\hline & 28 & & Grey Bush Chat & Saxicola ferreus & $\mathrm{R}$ & LC \\
\hline & 29 & Ploceidae & Baya weaver & Ploceus philippinus & $\mathrm{R}$ & $\mathrm{LC}$ \\
\hline & 30 & & Black-Breasted Weaver & Ploceus benghalensis & $\mathrm{R}$ & LC \\
\hline & 31 & Dicruridae & Black Drongo & Dicrurus macrocercus & $\mathrm{R}$ & $\mathrm{LC}$ \\
\hline & 32 & Passeridae & House Sparrow & Passer domesticus & $\mathrm{R}$ & $\mathrm{LC}$ \\
\hline & 33 & & Spanish Sparrow & Passer hispaniolensis & $\mathrm{M}$ & $\mathrm{LC}$ \\
\hline & 34 & Oriolidae & Eurasian Golden Oriole & Oriolus oriolus & $\mathrm{R}$ & LC \\
\hline & 35 & Corvidae & house crow & Orvus splendens & $\mathrm{R}$ & $\mathrm{LC}$ \\
\hline & 36 & Nectariniidae & purple sunbird & Cinnyris asiaticus & $\mathrm{M}$ & LC \\
\hline
\end{tabular}




\begin{tabular}{llllll}
\hline 37 & Pycnonotidae & Red-Vented bulbul & Pycnonotus cafer & $\mathrm{R}$ & $\mathrm{LC}$ \\
38 & Hirundinidae & Rock Martin & Ptyonoprogne fuligula & $\mathrm{M}$ & LC \\
39 & Cisticolidae & Rufous-Fronted Prinia & Prinia buchanani & $\mathrm{M}$ & LC \\
40 & Sylviidae & Orphean Warbler order & Sylvia hortensis & $\mathrm{M}$ & LC \\
41 & Muscicapidae & Rufous-Tailed Scrub Robin & Cercotrichas galactotes & $\mathrm{R}$ & LC \\
\hline
\end{tabular}

$\mathrm{M}=$ Migrant birds species, $\mathrm{R}=$ Resident Birds species

IUCN = International Union for Conservation of Nature and Natural Resources LC $=$ Least Concern * The information is based on the IUCN Red List (IUCN 2011)

Table 2 Relative abundance of wild birds at Sheikh Badin National Park.

\begin{tabular}{|c|c|c|c|c|}
\hline Species Name & Count & $\mathbf{P i}$ & LN"Pi" & $\mathbf{P i}^{*} \mathbf{L N} " \mathbf{P i}$ \\
\hline Shikra & 39 & 0.01 & -4.470 & -0.0511 \\
\hline Common Buzzard & 45 & 0.01 & -4.327 & -0.0571 \\
\hline Alpine Swift & 174 & 0.05 & -2.974 & -0.1518 \\
\hline Common Hoopoe & 68 & 0.02 & -3.914 & -0.0781 \\
\hline Red-wattled lapwing & 88 & 0.03 & -3.656 & -0.0944 \\
\hline Eurasian collared dove & 79 & 0.02 & -3.764 & -0.0872 \\
\hline Red Collared Dove & 66 & 0.02 & -3.944 & -0.0763 \\
\hline Spotted Dove & 72 & 0.02 & -3.857 & -0.0814 \\
\hline Rock Pigeon & 58 & 0.02 & -4.073 & -0.0693 \\
\hline Indian Roller & 63 & 0.02 & -3.990 & -0.0737 \\
\hline Blue-Checked Bee-Eater & 219 & 0.06 & -2.744 & -0.1763 \\
\hline Green Bee-Eater & 119 & 0.03 & -3.354 & -0.1171 \\
\hline Asian koel & 58 & 0.02 & -4.073 & -0.0693 \\
\hline Pied Cuckoo & 63 & 0.02 & -3.990 & -0.0737 \\
\hline Greater coucal & 50 & 0.01 & -4.221 & -0.0619 \\
\hline common kestrel & 21 & 0.01 & -5.089 & -0.0313 \\
\hline Black Francolin & 35 & 0.01 & -4.578 & -0.0470 \\
\hline Chukar & 14 & 0.01 & -5.494 & -0.0225 \\
\hline Common Quail & 113 & 0.03 & -3.406 & -0.1129 \\
\hline Grey Francolin & 84 & 0.02 & -3.703 & -0.0912 \\
\hline See-See Partridge & 38 & 0.01 & -4.496 & -0.0501 \\
\hline Bay-backed shrike & 75 & 0.02 & -3.816 & -0.0839 \\
\hline Red Backed Shrike & 52 & 0.02 & -4.182 & -0.0638 \\
\hline Common Myna & 124 & 0.04 & -3.313 & -0.1205 \\
\hline Common Stone Chat & 41 & 0.01 & -4.420 & -0.0531 \\
\hline Indian Robin & 115 & 0.03 & -3.388 & -0.1143 \\
\hline Isabelline Wheatear & 40 & 0.01 & -4.445 & -0.0521 \\
\hline Grey Bush Chat & 90 & 0.03 & -3.634 & -0.0959 \\
\hline Baya weaver & 174 & 0.05 & -2.974 & -0.1518 \\
\hline Black-Breasted Weaver & 122 & 0.04 & -3.329 & -0.1192 \\
\hline Black Drongo & 61 & 0.02 & -4.023 & -0.0720 \\
\hline House Sparrow & 252 & 0.07 & -2.604 & -0.1925 \\
\hline Spanish Sparrow & 108 & 0.03 & -3.451 & -0.1093 \\
\hline Eurasian Golden Oriole & 48 & 0.01 & -4.262 & -0.0600 \\
\hline House crow & 147 & 0.04 & -3.143 & -0.1355 \\
\hline purple sunbird & 71 & 0.02 & -3.871 & -0.0806 \\
\hline Red-Vented bulbul & 111 & 0.03 & -3.424 & -0.1115 \\
\hline Rock Martin & 52 & 0.02 & -4.182 & -0.0638 \\
\hline Rufous-Fronted Prinia & 38 & 0.01 & -4.496 & -0.0501 \\
\hline Orphean Warbler order & 39 & 0.01 & -4.470 & -0.0511 \\
\hline \multirow[t]{2}{*}{ Rufous-Tailed Scrub Robin } & 82 & 0.02 & -3.727 & -0.0896 \\
\hline & 3408 & 1 & -159.29 & 3.5465 \\
\hline
\end{tabular}


Table 3. Relative abundance of migrant wild birds in the Sheikh Badin National Park.

\begin{tabular}{lcccc}
\hline Species Name & Count & Pi & LN"Pi" & Pi*LN"Pi" $^{*} \mathbf{l}$ \\
\hline Shikra & 39 & 0.03 & -3.475 & -0.108 \\
Common Buzzard & 45 & 0.04 & -3.332 & -0.119 \\
Alpine Swift & 174 & 0.14 & -1.98 & -0.273 \\
Common Hoopoe & 68 & 0.05 & -2.919 & -0.158 \\
Indian Roller & 63 & 0.05 & -2.996 & -0.15 \\
Pied Cuckoo & 63 & 0.05 & -2.996 & -0.15 \\
Common kestrel & 21 & 0.02 & -4.094 & -0.068 \\
Common Quail & 113 & 0.09 & -2.411 & -0.216 \\
Bay-backed shrike & 75 & 0.06 & -2.821 & -0.168 \\
Red Backed Shrike & 52 & 0.04 & -3.188 & -0.132 \\
Common Stone Chat & 41 & 0.03 & -3.425 & -0.111 \\
Indian Robin & 115 & 0.09 & -2.394 & -0.218 \\
Isabelline Wheatear & 40 & 0.03 & -3.45 & -0.11 \\
Spanish Sparrow & 108 & 0.09 & -2.457 & -0.211 \\
purple sunbird & 71 & 0.06 & -2.876 & -0.162 \\
Rock Martin & 52 & 0.04 & -3.188 & -0.132 \\
Rufous-Fronted Prinia & 38 & 0.03 & -3.501 & -0.106 \\
Orphean Warbler order & 82 & 0.07 & -2.732 & -0.178 \\
& 1260 & 1 & 54.24 & 2.768 \\
\hline
\end{tabular}

Table 4. Relative abundance of resident wild birds in the Sheikh Badin National Park.

\begin{tabular}{lcccc}
\hline Species Name & Count & Pi & LN"Pi" & Pi $^{*} \mathbf{L N} \mathbf{P i}^{*}$ \\
\hline Red-wattled lapwing & 88 & 0.04 & -3.195 & -0.131 \\
Eurasian collared dove & 79 & 0.04 & -3.303 & -0.121 \\
Red Collared Dove & 66 & 0.03 & -3.483 & -0.107 \\
Spotted Dove & 72 & 0.03 & -3.396 & -0.114 \\
Rock Pigeon & 58 & 0.03 & -3.612 & -0.098 \\
Blue-Checked Bee-Eater & 219 & 0.1 & -2.283 & -0.233 \\
Green Bee-Eater & 119 & 0.06 & -2.893 & -0.16 \\
Asian koel & 58 & 0.03 & -3.612 & -0.098 \\
Greater coucal & 50 & 0.02 & -3.76 & -0.088 \\
Black Francolin & 35 & 0.02 & -4.117 & -0.067 \\
Chukar & 14 & 0.01 & -5.033 & -0.033 \\
Grey Francolin & 84 & 0.04 & -3.241 & -0.127 \\
See-See Partridge & 38 & 0.02 & -4.035 & -0.071 \\
Common Myna & 124 & 0.06 & -2.852 & -0.165 \\
Grey Bush Chat & 90 & 0.04 & -3.172 & -0.133 \\
Baya weaver & 174 & 0.08 & -2.513 & -0.204 \\
Black-Breasted Weaver & 122 & 0.06 & -2.868 & -0.163 \\
Black Drongo & 61 & 0.03 & -3.561 & -0.101 \\
House Sparrow & 252 & 0.12 & -2.143 & -0.251 \\
Eurasian Golden Oriole & 48 & 0.02 & -3.801 & -0.085 \\
House crow & 147 & 0.07 & -2.682 & -0.184 \\
Red-Vented bulbul & 111 & 0.05 & -2.963 & -0.153 \\
Rufous-Tailed Scrub Robin & 39 & 0.02 & -4.009 & -0.073 \\
& 2148 & 1 & -76.53 & 2.958 \\
\hline
\end{tabular}

\section{DISCUSSION}

In this study bird species diversity of the Sheikh Badin National Park was determined using the line- transect method. Moreover, species richness, current status, number of endangered habitat for species following the decline in birds' and also to identify causes of abrupt decline along with references and engagements for conservation of the bird's population in the Sheikh 
Badin National Park, Dera Ismail Khan, Pakistan were also evaluated. In our study the total number of wild bird species was 3408 including 41 wild bird species with 18 seasonal and 23 residential, belongs to 11 Orders and 25 Families respectively. The dominant order was Passeriformes with 19 species recorded from 13 families, including 9 residential and 10 seasonal species. Whereas order Galliformes with 5 belongs from one family, one seasonal and 4 residential while, order Columbiformes with 4 residential species belongs from one family. The lower orders in numbers were Apodiformes, including one species of Accipitridae family, Bucerotiformes, with one species from Upupidae family, Charadriiformes, with one species from Charadriidae family and Passerine, having one species from Muscicapidae family respectively. A comprehensive study conducted by (Raza et al. 2015) correlated with our study results with dominant one order as Passeriformes with species $(n=29)$ belongs to 17 families following the second order with species $(n=3)$ belongs to 2 families.

Moreover, their results also indicated the number of species $(\mathrm{n}=2)$ belongs from two separated families in order Coraciiformes. While the other orders, follow the sequence as; Gruiformes, Piciformes, Falconiformes, Ciconiiformes, Psittaciformes and Columbiformes, with 3, 3, 3, 2, 2, 2 species respectively belong to a single-family. Spatio-temporal conditions like shelter, less anthropogenic interventions, food, water are the factors have great influence on the relative abundance of bird species within a specific habitat.

Table 1 shows that all the 3408 species belong to 11 orders of birds were encountered in the Sheikh Badin National Park during the study period. Of these, according to the International Union for Conservation of Nature and Natural Resources (IUCN), all the species are "least concern" while study conduct in Jhunjhunu district (Deependra Singh Shekhawat and Chhaya Bhatnagar 2014) concluded that 2 species are classified as "critically endangered"; 1 species, "endangered"; two species, "near threatened"; and the remaining 96 species, "least concern". Our study results showed the species richness $(\mathrm{r}=41)$, Shannon-Weiner diversity index $\left(\mathrm{H}^{\prime}=3.546\right)$, evenness ( $\mathrm{J}^{\prime}$ 0.955) and Simpson's Diversity $(\mathrm{D}=0.966)$. Mengesha and Bekele (2008) mentioned that habitat heterogeneity and the importance of a specific area depends on a variety of individuals and species and avian diversity. Bibi and Ali (2013) also mentioned that the values of Shannon-Weiner Diversity Index usually falls between 1.5 and 3.5; however, in rare conditions, it surpasses 4.5. Variations in different factors like bird species diversity following species richness and species abundance are associated with vegetation of specific area. The vegetation composition alter nesting, food sources and protection, according to birds feeding and habitat preferences (Kiros et al., 2018). According to Lande et al., (2000), to limit the diversity for minor sample size Simpson Diversity index has swift convergence. Hence it is suitable for the evaluation of regions regarding species conservation. As Shannon Weiner diversity index was used to associate relative richness and species abundance amongst the species, also a source to specify the relative occurrence of many species (Whittaker, 1977; Barbour et al., 1998). Here in the present study the calculated values of the Shannon Weiner diversity index were 3.546, showed that the all species and individuals are uniformly distributed in the study area. These findings were also related to a study conducted by Ali (2006) which also shows the Shannon Weiner diversity index value as 3.99. Moreover, comprehensive field observations and findings of (Ali et al., 2011) at Taunsa Barrage Wildlife Sanctuary also showed that resident birds species and visitors species of winter and summer were evenly distributed in the study area. The majority of birds in the current study recorded were granivorous followed by insectivorous birds.

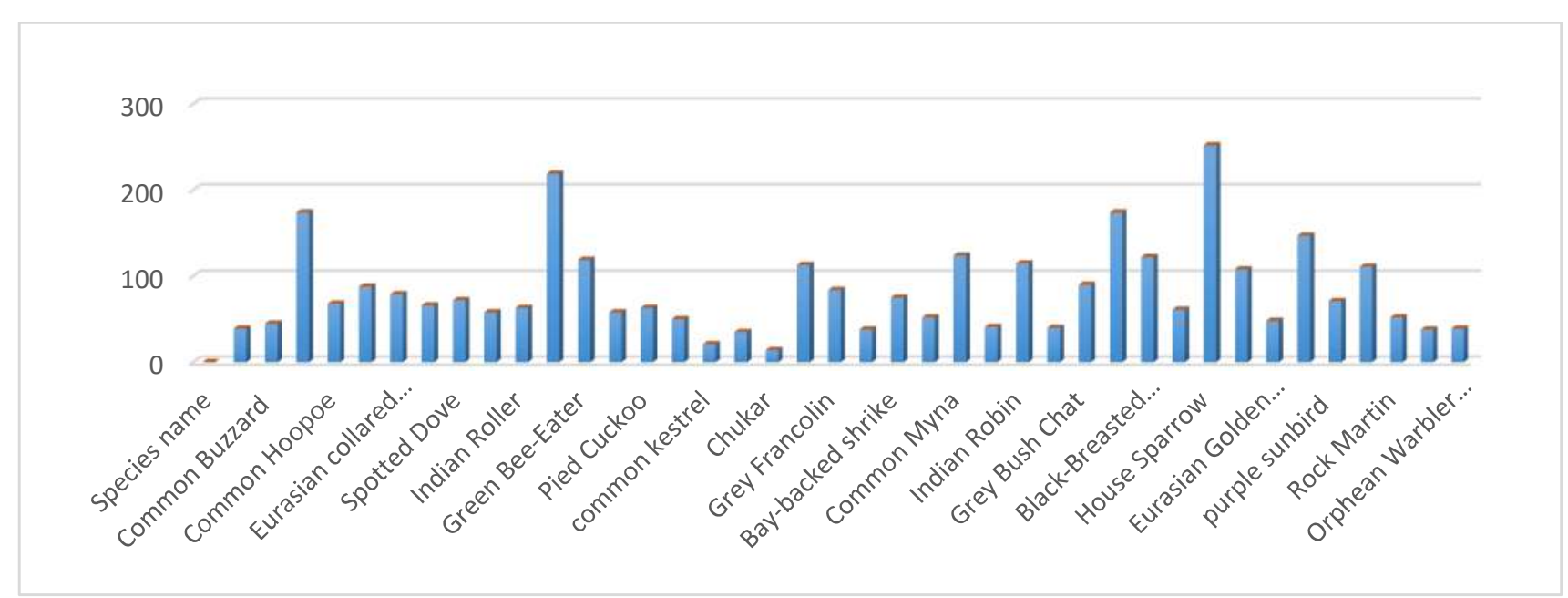

Figure 2. The number of bird species recorded at conducted study area. 
Threats to Avifauna Observed at Study Site: Following major threats has been observed in the Sheikh Badin National Park for the avifauna

Hunting: Prohibited and illegal hunting of bids by local community leads towards an interruption in feeding and breeding of birds. In the current study observed that mostly in the summer season people doing unlawful hunting of the birds through guns and nets. Which is directly effecting on the bird's population and breeding also. Mostly they are doing the hunting of Galliformes order and now the francolins are near to threatened in this area. It is illustrated that the drowning of ducks in fishing nets has been a major problem presented by Scott (1989). Likewise, hunting is a major problem creates a drastic disturbance in wildfowl (ducks) and other bird species that is the reason birds generally shift their feeding and resting places or schedules (Khan, 1992). In the park, the wildlife department clearly displays, sign boards and poster, i.e., hunting is strictly prohibite in the park area. However, the local peoples hunts on chukors, partridges, pigeons and doves illegally due to that the gamebird species decreasing quickly.

Deforestation: The other threat which was observed in the conducted study area was the deforestation. For avifauna, a suitable habitat is required to obtain their food and also for nesting and breeding. Bit due to deforestation now they are migrating for breeding to other areas.

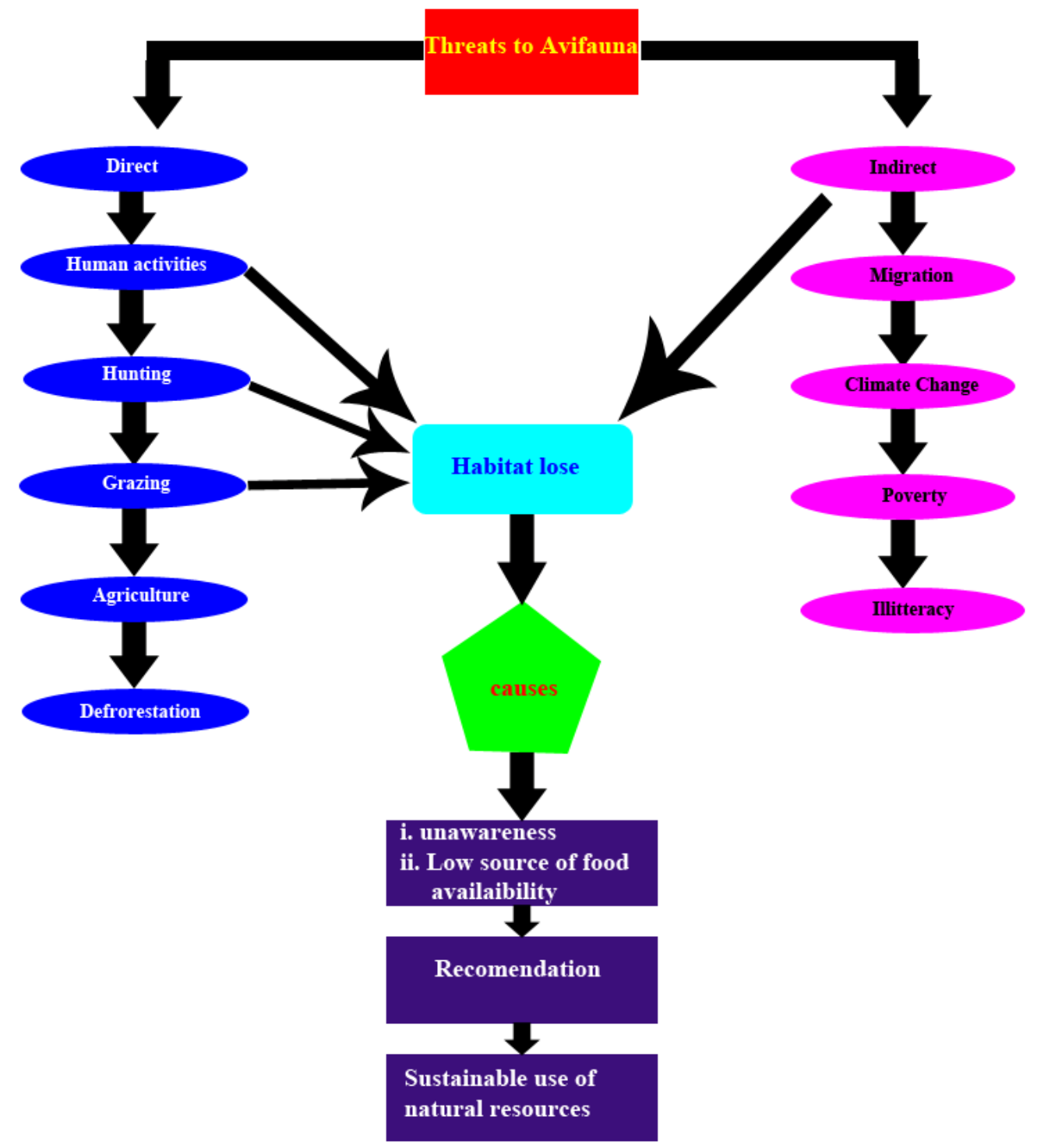

Fig 2. Showing the threats to avifauna at the conducted study area.

Influence of Grazing: Human activities affect include grazing of livestock results in flushing of nests of birds by rain when these are made due to availability of less hay material for nesting birds. Shortage of hay matter 
assists predators of birds to approach the eggs or chicks of breeding birds (Khan, 1992), while, wandering of livestock in the current study area was a significant threat to species of bird's survivorship. In the park, the wildlife department clearly displays boards and poster that keep away the animals from grazing in the park area.

Conclusion: This study determined abundance, status and endangered habitat. In culmination of the present study revealed a significant decline in Galliformes in the Sheikh Badin National Park due to unchecked and uncontrolled habitat destruction, hunting and grazing. This area harbor the higher bird diversity, e.g., ShannonWeiner index $\left(\mathrm{H}^{\prime}=3.546\right)$. This might be due to stability and functions of the ecological interactions that attracted a wide array of avian species. Hence, there is an urgent need for the conservation of avian diversity by protecting the natural habitat. In addition, the concern departments should control the unlawful activities, i.e., illegal hunting, uncontrolled grazing, and deforestation in the study area through implementing the wildlife act 2014.

Acknowledgements: Authors are highly thankful to Shubana Luqman (M.Phil. Zooogy), Miss Zarnab Gul (BS Botany), Raheem Ullah (BS Zoology) and Luqman Amin (BS Zoology) for their help in the data collection and compiling. In addition, we are grateful to Dr Amjad for guidance in data analysis and manuscript writting.

Funding: This paper was supported by the Fundamental Research Funds for the Central Universities, China (2572019BE04).

\section{REFERENCES}

Ali, Z (2006). Avian species analysis at three major wet lands complex Pakistan. Biologia. 52(2): 203213.

Ali, Z., F. Bibi, S.S. Shelly, A. Qazi and A.M. Khan (2011). Comparative avian faunal diversity of Jiwani Coastal Wetland sand Taunsa Barrage Wildlife Sanctuary, Pakistan. The J. Animal and Plant Science. 21(2): 381-387.

Amano, T., T. Székely, K. Koyama, H. Amano and W. J. Sutherland (2010b). A frame work for monitoring the status of populations: An example from wader populations in the East Asian-Australasian flyway. Biol.Conserv. 143(9): 2238-2247.

Barbour, M.G., J.H. Burk, W.D. Pitts, F.S. Gilliam and M.W. Schwartz (1998). Terrestrial Plant Ecology. Third Edition Benjarmin/Cummings: MenloPark California.

Becker, P.H (2003). Biomonitoring with bird. In Bioindicators and biomonitors, (Markert, B.A., A.M. Breure and M.C. Zechmeister. Eds.). Amsterdam: Elsevier Science Ltd.p.677-736.
Bhattacharjee, P.C. and B.C. Hazarika (1985). Roosting sites and roosting birds at Gauhati Municipal area. Second International Symposiumon Life Sciences, 14-16 November, 1985, NEHUS hillong.

Bibi, F. and Z. Ali (2013). Measurement of diversity indices of avian communities at Taunsa Barrage Wildlife Sanctuary, Pakistan. The J. Anim. and Plant Sciences. 23(2): 469-474.

Bird Life International (2004). State of the World's Birds: Indicators for Our Changing World. Bird Life International Cambridge, UK. p.28.

Chakravarty, A.K. (1981). Effects of human interference on water fowl of poolsin Bangalore (Karnataka), India. In Symposiumon Tropical Ecology, (Ambasht, R.S. and H.N. Pandey Eds.). Silver Jubliee, 5-10 October 1981 Bhopal.p.37-38.

Deependra, S.S. and C. Bhatnagar (2014). Guild, status, and diversity of avian fauna in the Jhunjhunu district, Rajasthan, India. J. Asia-Pacific Biodiversity.7: 262-267

Gole, P. (1984): Birds of a polluted river. J. Bomb. Nat. Hist. Soc. 81: 613-625.

Grimmett, R.C. and T. Inskipp (2001). Birds of Indian Subcontinent, Christopher Helm, London. P.384.

Hetrick, S.A. and K.E. Sieving (2012). Anti predator calls of tufted titmice and interspecific transfer of encoded threat information. Behav.Ecol. 23(1): 83-92.

Hewson, C.M., A. Amar, J.A. Lindsell, R.M. Thewlis, S. Butler, K. Smith and R.J. Fuller (2007). Recent changes in bird populations in British broad leaved woodland. Ibis.149(2): 14-28.

Khan, A.A., R. Khan, A. Ullah, M. Ali, J.A. Mahmood and K.M. Sheikh (1996). Conservation Perspectives of the Imperial Aquila heliacal and Steppe Eagle Aquilani palensisin Pakistan. Meyburg,B.U. and R.D. Chancelloreds. Eagle Studies World Walking Group on Birds of Prey (WWGBP) Berlin, London and Paris.P.3.

Khan, A. A. (1992). Activity budget and population analyses of waterfowl and wetland management of Sultan marshes (Sultan Sazligi). Ph.D. thesis Middle East Technical University-Ankara.

Kiros, S., B. Afework and K. Legese (2018). A preliminary study on bird diversity and abundance from Wabe fragmented forests around Gubresub city and Wolkite town, southwesternEthiopia.International J. Avian and Wildlife Biology. 3(5): 333-340.

Kushlan, J.A. (1993). Colonial water birds as bioindicators of environmental change. Coloni Waterbir. 16(2): 223-251. 
Lande, R. (1996). Statistics and partitioning of species diversity and similarity among multiple communities. Oikos. 76: 5-13.

Lande, R., P. J. Devries and T. R. Walla (2000). When species accumulation curves intersect: implications for ranking diversity using small samples. Oikos. 89: 601-605.

Luck, G.W., G.C. Daily and P.R. Ehrlich (2003). Population diversity and ecosystem services. Tren Ecol Evol. 18(7): 331-336.

Manakadan, R. and S. Pittie (2001). Standardised common and scientific names of the birds of the Indian subcontinent. Buceros. 6: 1-37.

Mengesha, G. and A. Bekele (2008). Diversity and relative abundance of birds of Alatish National Park, NorthGondar, Ethiopia. International J. Ecology and Environmental Sciences. 34(2): 215-222.

Mirza, Z. and H. Wasiq (2007). A field guide to birds of Pakistan. Published by WWF-Pakistan, Bookland Lahore.p. 366.

Raza, H., S. Mehmood, B.N. Khan, F. Bibi, and Z. Ali, Z (2015). Avian diversity of Lahore Safari Zoo in winter season Lahore, Pakistan. J. Anim Pl Sci. 25(Suppl. 2): 378-381

Sandhu, P.S. and H.R. Dang (1980). Roosting behavior of parakeets in relation to human disturbance.
Second All India Symposium on Life Sciences, 9-11 March 1980.

Sharma, I.K. (1982). Adverse effects of air, water and soil pollutions on flora and fauna of towns and villages of Western Rajasthan. Symposium on Environment Consciousness, Problems of Pollution and Conservation in Rajasthan, 1-3 October 1982.

Sibley, C.G. and B.L. Monroe (1990). Distribution and Taxonomy ofBirds of the World. New Haven, CT, Yale Unversity Press.

Simpson, E. H. (1949). Measurement of diversity. Nature, 163: 68.

Talukdar, B.. (1997). Water birds of Dibru-saikhowa wild life sanctuary. Assam J. Nat Cons. 9(2): 243250.

Trivedi, P.R. 1999). Wildlife reserves and national parks in India. I Encyclopedia of ecology and environment. New Delhi, India. Indian Institute of Ecology and Environment (IIEE).p. 23-25.

Whittaker, R.. (1977). Evolution of species diversity on land communties. Evolutionary Biology. 10: 167.

Yasué, M. andP. Dearden (2006). The potential impact of tourism develpment on habitat availability and productivity of Malaysian plovers Charadriusperonii. J. Appl Ecol. 43(5): 978989. 